Fernando Pacheco Torgal · J.A. Labrincha M.V. Diamanti - C. P. Yu

H.K. Lee Editors

Biotechnologies

and Biomimetics

for Civil

Engineering

Springer 


\section{Editors}

Fernando Pacheco Torgal

C-TAC Research Unit

University of Minho

Guimarães

Portugal

\author{
J.A. Labrincha \\ CICECO \\ University of Aveiro \\ Aveiro \\ Portugal
}

M.V. Diamanti

Politecnico di Milano

Milan

Italy

\author{
C.-P. Yu \\ Chinese Academy of Sciences \\ Institute of Urban Environment \\ Xiamen \\ China
}

\author{
H.K. Lee \\ Korea Advanced Institute of Science \\ and Technology \\ Daejeon \\ Korea \\ Republic of South Korea
}

ISBN 978-3-319-09286-7 ISBN 978-3-319-09287-4 (eBook)

DOI 10.1007/978-3-319-09287-4

Library of Congress Control Number: 2014947704

Springer Cham Heidelberg New York Dordrecht London

(C) Springer International Publishing Switzerland 2015

This work is subject to copyright. All rights are reserved by the Publisher, whether the whole or part of the material is concerned, specifically the rights of translation, reprinting, reuse of illustrations, recitation, broadcasting, reproduction on microfilms or in any other physical way, and transmission or information storage and retrieval, electronic adaptation, computer software, or by similar or dissimilar methodology now known or hereafter developed. Exempted from this legal reservation are brief excerpts in connection with reviews or scholarly analysis or material supplied specifically for the purpose of being entered and executed on a computer system, for exclusive use by the purchaser of the work. Duplication of this publication or parts thereof is permitted only under the provisions of the Copyright Law of the Publisher's location, in its current version, and permission for use must always be obtained from Springer. Permissions for use may be obtained through RightsLink at the Copyright Clearance Center. Violations are liable to prosecution under the respective Copyright Law. The use of general descriptive names, registered names, trademarks, service marks, etc. in this publication does not imply, even in the absence of a specific statement, that such names are exempt from the relevant protective laws and regulations and therefore free for general use.

While the advice and information in this book are believed to be true and accurate at the date of publication, neither the authors nor the editors nor the publisher can accept any legal responsibility for any errors or omissions that may be made. The publisher makes no warranty, express or implied, with respect to the material contained herein.

Printed on acid-free paper

Springer is part of Springer Science+Business Media (www.springer.com) 
I am confident that humanity's survival depends on all of our willingness to comprehend feelingly the way nature works

Buckminster Fuller 
Fernando Pacheco Torgal · J. A. Labrincha · M. V. Diamanti · C.-P. Yu · H. K. Lee Editors

\section{Biotechnologies and Biomimetics for Civil Engineering}

Biomimetics is at the interfaces of biology, engineering, material science and chemistry and encourages an open dialogue which can bring enlightenment about problems as displayed in this book.

Emeritus Professor Derek Clements-Croome, University of Reading (from the Foreword)

Putting forward an innovative approach to solving current technological problems faced by human society, this book encompasses a holistic way of perceiving the potential of natural systems. Nature has developed several materials and processes which both maintain an optimal performance and are also totally biodegradable, properties which can be used in civil engineering.

Delivering the latest research findings to building industry professionals and other practitioners, as well as containing information useful to the public, 'Biotechnologies and Biomimetics for Civil Engineering' serves as an important tool to tackle the challenges of a more sustainable construction industry and the future of buildings.

Materials Science/

Engineering

I SBN $978-3-319-09286-7$

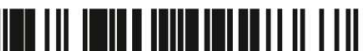




\title{
Chapter 1 \\ Introduction to Biotechnologies and Biomimetics for Civil Engineering
}

\author{
F. Pacheco-Torgal
}

\begin{abstract}
This chapter starts with an overview on the sustainable development crucial challenges. The ones directly or indirectly related to the field of civil engineering are highlighted. These include greenhouse gas emissions (GHG) related to the energy consumption of the built environment, aggravated by urbanization forecast expansion, and the recent increase in building cooling needs due to climate change. It also includes the depletion of nonrenewable raw materials and mining-related environmental risks in terms of biodiversity conservation, air pollution, and contamination of water reserves. Some shortcomings of engineering curriculum to address sustainable development challenges (especially civil engineering) are described. Possible contributions of biotechnologies and biomimetics to sustainable development and the rebirth of civil engineering curriculum are suggested. A book outline is also presented.
\end{abstract}

\subsection{Sustainable Development Challenges}

Four decades ago several investigators used a computer model based on the fixedstock paradigm to study the interactions between population, food production, industrial production, pollution, and the consumption of nonrenewable resources. As a result, they predicted that during the twenty-first century the Earth's capacity would be exhausted resulting in the collapse of human civilization as we know it Meadows et al. (1972). Two decades after that an update of this study was published showing that some limits had already been crossed (Meadows et al. 1992).

Rockström et al. (2009) recently proposed a new approach to global sustainability defining nine interdependent planetary boundaries within which they expect that humanity can operate safely. This include:

\footnotetext{
F. Pacheco-Torgal ( $\square)$

C-TAC Research Centre, University of Minho, Guimarães, Portugal

e-mail: torgal@civil.uminho.pt
}

F. Pacheco Torgal et al. (eds.), Biotechnologies and Biomimetics for Civil Engineering,

DOI 10.1007/978-3-319-09287-4_1 
(1) climate change $\left(\mathrm{CO}_{2}\right.$ concentration in the atmosphere $<350 \mathrm{ppm}$ and/or a maximum change of $+1 \mathrm{~W} \mathrm{~m}^{-2}$ in radiative forcing);

(2) ocean acidification (mean surface seawater saturation state with respect to aragonite $\geq 80 \%$ of pre-industrial levels);

(3) stratospheric ozone $\left(<5 \%\right.$ reduction in $\mathrm{O}_{3}$ concentration from pre-industrial level of 290 Dobson Units);

(4) biogeochemical nitrogen $(\mathrm{N})$ cycle (limit industrial and agricultural fixation of $\mathrm{N}_{2}$ to $35 \mathrm{Tg} \mathrm{N} \mathrm{yr}^{-1}$ ) and phosphorus (P) cycle (annual $\mathrm{P}$ inflow to oceans not to exceed 10 times the natural background weathering of $\mathrm{P}$ );

(5) global freshwater use $\left(<4,000 \mathrm{~km}^{3} \mathrm{yr}^{-1}\right.$ of consumptive use of runoff resources);

(6) land system change ( $<15 \%$ of the ice-free land surface under cropland);

(7) the rate at which biological diversity is lost (annual rate of $<10$ extinctions per million species).

Two additional planetary boundaries for which a boundary level was not yet determined are chemical pollution and atmospheric aerosol loading.

According to Rockström et al. (2009) "transgressing one or more planetary boundaries may be deleterious or even catastrophic due to the risk of crossing thresholds that will trigger nonlinear, abrupt environmental change within continental- to planetary-scale systems". These authors estimated that humanity has already transgressed three planetary boundaries for climate change, rate of biodiversity loss, and changes to the global nitrogen cycle. And a recent study (Garcia et al. 2014) confirms the devastating impacts of climate change on biodiversity loss. As a consequence of this worrying status, it remains crucial to act in order to address those problems in a context in which urban human population will almost double, increasing from approximately 3.4 billion in 2009 to 6.4 billion in 2050 (WHO 2014). Other authors also agree that this is the most vital challenge of the twenty-first century (Griggs et al. 2013; Gerst et al. 2014). As Spence et al. (2009) have showed this increase in urban population is economically motivated. The higher the urbanization rate of a country, the higher its GDP. Countries high a GDP per person over $\$ 10.000$ have a urbanization rate over $60 \%$ while countries with a GDP per person over $\$ 30.000$ have a urbanization rate around $80 \%$. Internally the economic importance of working in cities can be assessed by the urban-rural income gap. In China the urban-rural residents' income ratio surged from 2.57:1 in 1978 to 3.13:1 in 2011 ( $\mathrm{Li}$ et al. 2014a, b).

Climate change is one of the most important environmental problem faced by the Planet Earth (IPCC 2007; Schellnhuber 2008) being due to the increase of carbon dioxide $\left(\mathrm{CO}_{2 \mathrm{eq}}\right)$ in the atmosphere, for which the built environment is a significant contributor, with around one-third of global carbon dioxide emissions. In the early eighteenth century, the concentration level of atmospheric $\mathrm{CO}_{2 \mathrm{eq}}$ was 280 parts per million (ppm) at present it is already 450 ppm (Vijayavenkataraman et al. 2012).

Keeping the current level of emissions (which is unlikely given the high economic growth of less developed countries with consequent increases in emission rates) will 
imply a dramatic increase in $\mathrm{CO}_{2 \mathrm{eq}}$ concentration to as much as $731 \mathrm{ppm}$ in the year 2130 leading to a $3.7^{\circ} \mathrm{C}$ global warming above pre-industrial temperatures (Valero et al. 2011). Even if all the greenhouse gas emissions suddenly ceased, the amount already in the atmosphere would remain there for the next 100 years (Clayton 2001). Meaning the rise in the sea level, ocean acidification and the occurrence of extreme atmospheric events will continue. Hansen et al. (2013) are even more pessimistic believing that the climate has already been changed in an irreversible manner. A worrying sign that justifies Hansen's view comes from a recent study (McMillan et al. 2014) based on the measurements collected by the Cryosat-2 satellite which reported an annual loss of 159.000 million tons of the Antartic ice sheet. This represents a $200 \%$ ice loss rate when compared to the 2005-2010 previous survey. This means that adaptation to climate change as well as mitigation of GHGs should be a priority to the built environment (Kwok and Rajkovich 2010; Varias 2013; Boucher et al. 2014; Reckien et al. 2014; Georgescu et al. 2014). Even because buildings are responsible for almost $40 \%$ of energy consumption and energy efficiency improvements show the greatest potential of any single strategy to abate global GHG emissions from the energy sector (IEA 2012). And especially because as a consequence of climate change in the last two decades building cooling needs have increased in an exponential trend going from $6 \mathrm{TJ}$ in 1990 to $160 \mathrm{TJ}$ in 2010 (Balaras et al. 2007). According to Crawley (2008), "the impact of climate change will result in a reduction in building energy use of about $10 \%$ for buildings in cold climates, an increase of energy use of up to $20 \%$ for buildings in the tropics, and a shift from heating energy to cooling energy for buildings in temperate climates". Other authors mention that depending on the climate zone cooling loads are likely to increase by 50 to over $90 \%$ until the end of the century (Roetzel and Tsangrassoulis 2012). Cooling needs will also be aggravated because of urban heat island (UHI) effect, which is one of the major problems in the twenty-first century posed to human beings as a result of urbanization and industrialization of human civilization (Rizwan 2008). And this scenario will get even worse due to the expected increase in urban population and also of predict number of deaths due to heat waves (and their synergic effects with air pollution) that may reach 89,000 deaths/year by the 2050 s if no adaptation measures are taken (Pacheco-Torgal et al. 2015). This means that the energy efficiency of the built environment should and must constitute a priority in the field of civil engineering. However, only some parts of the world, like for instance Europe, are now start implementing ambitious building energy efficiency policies like for instance the "nearly zero-energy building" concept to be in effect beyond 2020 (Li et al. 2013; Pacheco-Torgal et al. 2013a, b). Since only several years ago, civil engineering curriculum starts giving this issue some attention. This means that the majority of civil engineering curriculum around the world are obsolete concerning building energy efficiency or the holistic and broader concept of green building (Zuo and Zhao 2014; Li et al. 2014a, b).

Another sustainable development serious problem which is directly related to the field of civil engineering concerns total resource inefficiency. Over the twentieth century, the world increased its fossil fuel use by a factor of 12 , whilst 
extracting 34 times more material resources (COM 2011). Also during the last century, materials use increased eightfold and, as a result, Humanity currently uses almost 60 billion tons (Gt) of materials per year (Krausmann et al. 2009). The global construction industry alone consumes more raw materials (about 3,000 Mt/ year, almost $50 \%$ by weight) than any other economic activity, which emphasizes its unsustainable character. Also, in the next few years, the construction industry will keep on growing at a fast pace. China alone will need 40 billion square meters of combined residential and commercial floor space over the next 20 yearsequivalent to adding one New York City every 2 years (Pacheco-Torgal and Jalali 2011). Recent estimates on urban expansion suggests that until 2030 a high probability exist (over $75 \%$ ) that urban land cover will increase by 1.2 million $\mathrm{km}^{2}$ (Seto et al. 2012). This is equivalent to an area about the size of South Africa. The forecast urban expansion could lead to the loss of up to $40 \%$ of the species and of $88 \%$ of the global primary vegetation land cover had been destroyed in "biodiversity hotspots" (Pim and Raven 2000; Myers et al. 2000).

The most important environmental threat associated to materials production is not so much the depletion of nonrenewable raw materials (Allwood et al. 2011), but instead, the environmental impacts caused by its extraction, namely extensive deforestation and top-soil loss. In 2000, the mining activity worldwide generated $6,000 \mathrm{Mt}$ of mine wastes to produce just $900 \mathrm{Mt}$ of raw materials (Whitmore 2006).

This means an average use of only $0.15 \%$, resulting in vast quantities of waste, whose disposal represents an environmental risk in terms of biodiversity conservation, air pollution, and contamination of water reserves. It is worth mention that around 1.2 billion people live in areas of physical scarcity and 500 million people are approaching this situation. As a result, since the 1970s there were 30 serious environmental accidents in mines, 5 of which occurred in Europe (Pacheco-Torgal and Jalali 2011) like for instance the 2010 toxic red mud flood in the town of Kolontar (Hungary). This is rather disturbing because Europe has high environmental standards which mean that countries in which such high standards do not exist environmental disasters could happen much more frequently. Since materials demand will double in the next 40 years, the environmental impacts will therefore increase in a drastic manner (Allwood et al. 2011). Consequently, the World Business Council for Sustainable Development estimates that by 2050 a 4 to 10-fold increase in resource efficiency will be needed (COM, 571). Alwood et al. (2011) recognizes that part of the problem is related to the fact that so far researchers have paid too little attention to the crucial issue of materials efficiency. A possible explanation for that gap relates to the fact that sustainable development principles have not yet been apprehended by University curricula. In recent years, several authors theorized about the way to embed sustainable development in higher education and several institutions made some efforts on this issue (Lozano 2006; Pacheco-Torgal and Jalali 2007; Holmberg et al. 2008; De Vere et al. 2009; Lozano 2010; Waheed et al. 2011). Data from a recent survey completed by final year engineering students in three Irish Higher Education Institutions shows that 
the engineering students' knowledge on this subject is still deficient (Nicolao and Colon 2012).

Salcedo-Rahola and Mulder (2009) state that "If engineers are to contribute truly to sustainable development, then sustainability must become part of their everyday thinking. This, on the other hand, can only be achieved if sustainable development becomes an integral part of engineering education programs, not a mere "add-on" to the "core' parts of the curriculum." As a result, the validation of any discipline in any engineering curriculum must be put to a test in which the one million dollar question is "How can your discipline contribute to sustainable development?" (Salcedo-Rahola and Mulder 2009). A more holistic approach is defended by Al-Rawahy (2013) who state that sustainable development has concentrated mainly on physical and tangible issues and assets and that that the most pressing ingredient and the most scarce resource facing the sustainability concept is the ethical and moral values that universities need to proactively and aggressively "infuse" into their respective curricula. This position was already defended by other authors. According to Dator (2005) "engineering is not more important than ethics... and science is not more important than policy and law" therefore a new kind of engineering education is therefore needed to address sustainable development principles. Grasso et al. (2010) mention that "a new kind of engineer is needed, one who can think broadly across disciplines and consider the human dimensions that are at the heart of every design challenge". This is especially important in the context of climate change, which raises many questions with ethical dimensions rooted in the human condition (Willis 2012; Kaklauskas et al. 2013).

\subsection{Civil Engineering: The Rebirth of an Obsolete Curriculum Through Biotechnologies and Biomimetics}

Recent studies show that students of civil and environmental engineering were reluctant to have sustainability integrated sustainability into existing classes (Watson et al. 2013). One of the latest trends concerning the update of civil engineering towards sustainable development is related to the inclusion of lifecycle assessment (LCA) skills in the education curriculum (Glass et al. 2013). Unfortunately, since almost all construction products are not environmentally friendly, this is the same as choosing between the less of two evils. Another drawback of LCA is the fact that it does not take into account the possible future environmental disasters associated with the extraction of raw materials. This means that, for instance, the LCA of the aluminum produced by the Magyar Aluminum factory, the one responsible for the toxic red mud flood in the town of Kolontar (Hungary), should account for this environmental disaster. Only then construction products will be associated with their true environmental impact. Since that it is almost impossible to put in practice this means that new and truly 
environmentally friendly construction materials are needed. However, not only is important that civil engineering curricula are updated so they may give future graduates appropriate skills to tackle the sustainable development challenges but it is also important that enough students are interested in following a career as civil engineers. Unfortunately, in the last decade, several Western countries have reported a severe applications reduction to civil engineering. A $50 \%$ reduction was reported on undergraduate applications to civil engineering in UK (Byfield 2001; Edwards et al. 2004). In the UK, a shortfall of 9,000 civil engineers is predicted to occur until 2013 (Byfield 2003).

Nedhi (2002) also confirms that civil engineering is not traditionally viewed as "high tech" engineering and, as a result, student quality and enrollment have been declining across North America. The same also applies in the case of research funding in civil engineering programs. This also reduces the possibility of attracting high grade students. Also in my own country (Portugal) the reduction on the enrollment ratio exceeded $80 \%$ in the last 5 years. To make matters worse, in the last 5 years, the grade of the last student to be admitted has fallen in all the top three Portuguese Universities meaning that civil engineering is less and less capable of attracting high grade students.

In the beginning of the twenty-first century, Yurtseven (2002) already mentioned that a general problem was common to all engineering professions thus affecting negatively the student recruitment. He stated that engineers were viewed as dull individuals by contrast "to the image of a true renaissance engineer, Leonardo da Vinci who was creative and literate... an accomplished painter, architect and scientist."

The explanation for that can be found in the words of Zielinski (2003) who states that "the traditional narrow technical formation produces graduates that are, using the German language expression "fachidiot." It is then of no surprise that engineers are often satirized as persons with zero social skills. For Hamill and Hodgkinson (2003), the responsibility lies in the "invisibility" of the civil engineering profession, the absence of positive role models, low starting salaries, and unattractive working conditions. Lawless (2005) mentions that South Africa faces the same recruitment problem. Adeli (2009) also mentions that the low enrollment ratio of students in civil and environmental engineering at many US universities constitutes a problem to be dealt with. This constitutes a strange fact in a country where civil engineering is viewed as a profession with high industry demand. India, a crucial worldwide player, is also facing a severe shortage of civil engineers to achieve its huge infrastructural development targets. Again, as it happens in the US, the demand is not the problem (construction industry in India needs civil engineers). This reason, however, however seems insufficient to motivate Indian students. Part of the explanation for the low attraction capability of civil engineering relates to the fact that, in India this course is viewed as "brick and mortar engineering" (Chakraborty et al. 2011). Even the "the word "civil" in "civil engineering" is anachronistic and does not represent the works of the so-called civil engineer." As a consequence, civil engineering is "the only engineering discipline to have a name that does not represent the works it undertakes" (Shings 2007). All of what was wrote can be seen 
as a proof that this curriculum is an obsolete one, which constitutes a worrying issue in the context of future of twenty-first century sustainable development challenges.

However, "recent" nanotechnology achievements regarding the replication of natural systems may provide a solution to solve some of the aforementioned sustainability challenges related to the field of civil engineering. Nanotechnology deals with an atom scale $\left(1 \mathrm{~nm}=1 \times 10^{-9} \mathrm{~m}\right)$. A hydrogen atom has a diameter of about one tenth of a nanometer and it takes six bonded carbon atoms to reach a nanometer width. In Nature there are innumerous examples of the nanoscale but one of the most interesting in the "civil engineering context" is the 1-2 nm hydrophobic wax crystals that cover lotus leaves and are responsible for their selfclean ability (Varadan et al. 2010). This new field encompasses a holistic way of perceiving the potential of natural systems (Martin et al. 2010) in which traditional and predominant anthropocentric views are replaced by more eco-centrically approaches (Hofstra and Huisingh 2014) as prerequisite in order to build a sustainable future. It is worth mentioning that this ecological imperative is very far from the 1828 Royal Charter of the Institution of Civil Engineers main purpose, which defined civil engineering as the art of "directing the great sources of power in nature for the use and convenience of man..." (Muir-Wood 2012). Strangely as may seems most civil engineering curriculum and most civil engineering departments in the world still live by this two century outdated and unsustainable motto and some even went to the paradox extreme of try to marketing it as a curriculum forged in sustainable development principles.

The crucial importance of Nature's lessons relates to the fact that it always uses ambient conditions with minimum waste and no pollution, where the result is mostly biodegradable by the contrary man-made materials are processed by heating and pressurizing generating enormous hazardous wastes (Bar-Cohen 2006). On her inspired book Benyus (1997) quoted Mehmet Sarikaya, Professor of material's science and engineering at the University of Washington who wrote: "We are on the brink of a material's revolution that will be on par with the Iron Age and the Industrial Revolution. We are leaping forward into a new age of materials. Within the next century, I think biomimetics, will significantly alter the way in which we live. Learning from nature can become a great challenge for future management". And in fact some more or less recent papers on biological materials (Sarikaya et al. 2003; Sanchez et al. 2005; Chen et al. 2012; Yang et al. 2013; Amini and Miserez 2013) especially the highly cited papers of Markaya et al. (with 823 Scopus citations by May of 2014) and of Sanchez et al. (with 517 Scopus citations by May of 2014) and the extensively detailed paper of Chen et al. serve as a confirmation of the 1997 Saikaya's predictions.

The Biomimicry Institute, founded in 2006 by Janine Benyus, was precursor in this field providing the AskNature online library of research articles on biomimetic design indexed by function. The term biomimetics was used by the first time by Otto Schmitt during the 1950s and relates to the development of novel technologies through the distillation of principles from the study of biological systems. This author made a distinction between an engineering/physics approach to the biological sciences, which was termed "biophysics," and a biological approach to 
engineering, which he termed biomimetics (Vincent et al. 2006; Lepora et al. 2013). However, the study of biological systems as structures dates back to the early parts of the twentieth century with the work of D'Arcy W. Thompson, first published in 1917. In this work that some authors considered the first major one on this field D'Arcy W. Thompson looked at biological systems as engineering structures and obtained mathematical relationships that described their form (Chen et al. 2012).

According to Vincent (2001), biomimetics is the "technological outcome of the act of borrowing ideas from nature" and this concept would have also been termed as "biomimesis", "biognosis," and "bionics." For this author, the term "bionics" was coined in 1960 by Jack Steele of the US Air Force. In German-speaking countries, the term "Bionik" has become widely accepted for the corresponding field to "Biomimetics." "Bionik" - combining biology and technology (Gebeshuber et al. 2009).

Figure 1.1 gives an overview of the history of biomimetics research. Terms such as "biomimicry," "bioinspiration," and "bioinspired" are derived words from "biomimetic," and "bioinspired" is sometimes used to connote a presumed heir of the word biomimetic (Shimomura 2010).

The publications on the field of biomimetics have experienced an amazing increase from a few 10 papers per year in mid-1990s to the present, doubling every 2-3 years and reaching an annual production of 3,000 papers in 2011 (Lepora et al. 2013). A recent search on Elsevier's Scopus revealed that in 2013 the number of

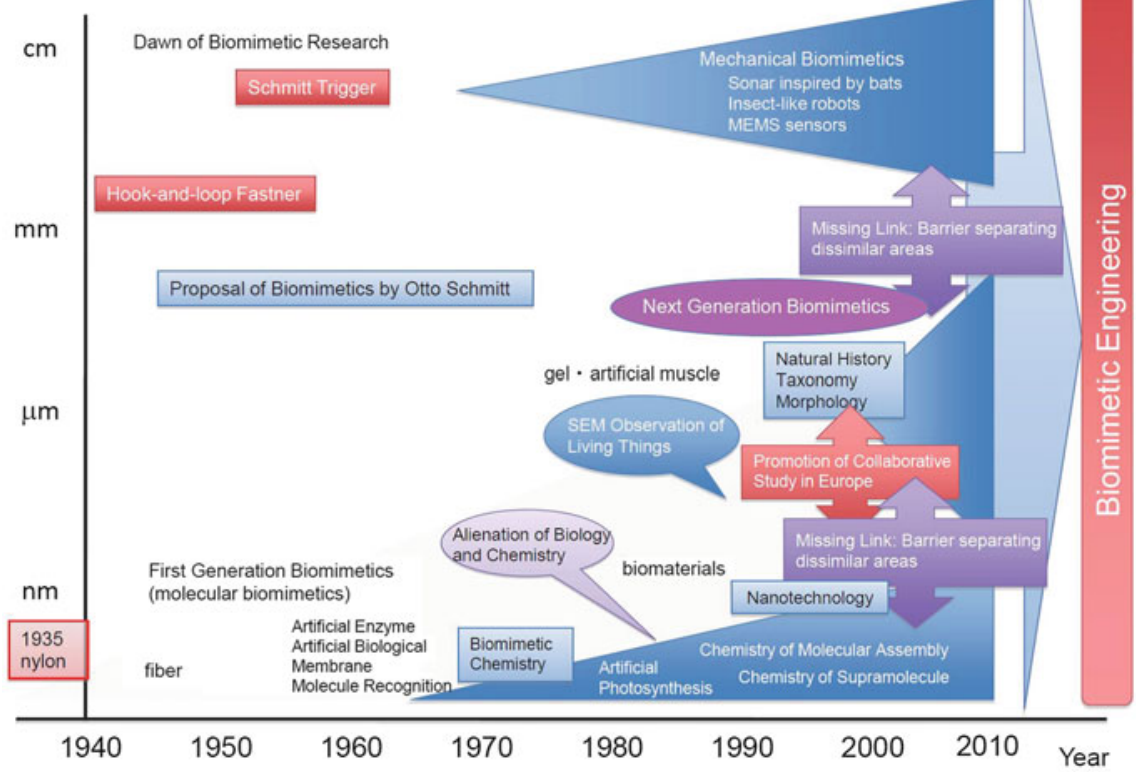

Fig. 1.1 History of biomimetics research (Simomura 2010) 
journal papers containing the search term biomimetic reached 12,913 , while the search term "bioinspiration" was found in 667 journal papers, and biomimicry in 380 .

Analysis of bioinspired materials requires knowledge of both biological and engineering principles. As Vincent (2006) rightly put it "if engineers are going to be able to use ideas from biology, it cannot be stated too often that the biological system must be understood before allowing ideas to be transferred into the engineering environment". Bar-Cohen (2006) states that bridging between the fields of biology and engineering is crucial to harness the most from nature's capabilities. This remind us the words of Sir Isaac Newton about the need of more bridges and less walls, which is especially truth on scientific knowledge. It is important to remember that biologists themselves have recently started establishing bridges with physicists to investigate the weird field of "quantum biology" (the term of "quantum biology" was first mentioned in the beginning of the second half of the twentieth century by Lowdin (1963)). Some recent investigations suggest that plants use quantum "computing" to calculate how best to direct energy through their photosynthetic complexes (Engel et al. 2007; Sarovar et al. 2010; Vedral 2014). Other also suggest that some birds appear to use "quantum entanglement" to sense the Earth's magnetic field, helping to explain how they can migrate long distances (BBSRC 2012). This "weird" concept posits that entangled particles, once separated, can somehow "communicate" with each other instantly so that that a change in one automatically changes the other was famous for having been referred by Albert Einstein as spooky action at a distance (Kaku 2010).

Vincent and Mann (2002) compared solutions of some engineering problems such as cleaning and joining surfaces by natural organisms with those by using the Russian system of problem solving (TRIZ) and noted that TRIZ seemed to have the main qualifications of an effective bridge between biology and engineering. The use of TRIZ is suggested to be able to facilitate the transfer of ideas and analogues from biology for engineering (Vincent et al. 2006; Vincent 2007). Other authors (Denghai and Wuyi 2011) proposed a four-step systematic method of structural bionic design: selecting the most useful structural characteristic of natural organism; analyzing the structural characteristic finally chosen for engineering problem; completing the structural bionic design for engineering structure; and verifying the structural bionic design.

The allocation of biomimetics education to either natural science or engineering schools seems to be difficult to implement in both cases (Gebeshuber et al. 2009). The fact that biologists and engineers typically speak a very different language, may create communication challenges (Helms et al. 2009). In the words of Gebeshuber and Majlis (2010), "the biology papers are frequently inaccessible for engineers, since they are too descriptive and contain concepts and approaches such as taxonomy with its Latin names that are too far from any concept in engineering". These authors thus suggest the establishment of a tree of knowledge and the localisation of scientific articles on this tree.

An important difference between engineers and biologist concerns standardization. While the former are very familiar with standards this is hardly the case of 
the latter. That's MIT scientist Tom Knight once wrote that those differences could be illustrated by the following example "A biologist goes into the lab, studies a system and finds that it is far more complex than anyone suspected. He's delighted, he can spend a lot of time exploring that complexity and writing papers about it. An engineer goes into the lab and makes the same finding. His response is: 'How can I get rid of this?'” Meaning that contrary to biologists engineers excel at eliminating irrelevant complexity in order to build something that works and is fully understood (Brown 2004; Rai 2010).

Three examples below highlight the importance of biotechnologies and biomimetics for civil engineering.

The first one relates to Ordinary Portland cement (OPC) concrete, a typical civil engineering construction material, being the most used material on the Planet Earth. Its production reaches 10.000 million tons/year and in the next 40 years will increase around $100 \%$ (Pacheco-Torgal et al. 2013a). Currently around $15 \%$ of the total OPC production contains chemical admixtures to modify their properties, either in fresh or hardened state. Concrete super plasticizers based on synthetic polymers include melamine, naphthalene condensates or polycarboxylate copolymers. Environmental concerns justify a growing trend to the use of admixtures based on renewable bio-based feedstocks and or capable of biodegradation. Examples of biopolymers used in concrete include for instance lignosulfonate, pine root extract, protein hydrolysates or even vegetable oils. Biotechnological admixtures processes made in fermentation processes by using bacteria or fungi seem to receive an increase attention. This includes sodium gluconate, curdlan or Welan gum (Planck 2004, 2005).

An important biomimetic application for civil engineering concerns bioinspired structural design. For instance, deployable structures can be mentioned among shape morphing structures that can change shape like the wing of the insects or the petals of the flowers or like the movable structure of human body (Friedman and Ibrahimbegovic 2013). These structures were born by the application of the basic ideas of tensegrities, as the foldable bridge realization, proposed by Rhode-Barbarigos et al. (2012). The tensegrity concept was born from the exceptional work of the inventor Buckminster Fuller (1962) aiming at maximal structural efficiency. He coined the word "tensegrity" from tensile integrity and defined it as "islands of compression inside an ocean of tension" (Kawaguchi 2002).

Snelson (1965) also worked on the tensegrity field termed as "floating compression" system and much later the cell biologist and bioengineer Ingber (1998) defined this concept as "the architecture of life."

Another important biomimetic civil engineering-related issue concerns biomimetic building "skins." The kinetics and adaptability implicit in this concept are quite the opposite of current trends on passive building design approach (Loonen et al. 2014; Schleicher et al. 2014; Reichert et al. 2014). Of course this concept would not make any sense in a heavy polluted city but only in a biophilic city. The concept of biophilia, popularized by Harvard myrmecologist and sociobiologist E.O. Wilson is defined as - the innately emotional affiliation of human beings to 
other living organisms. This author argues that humans have co-evolved with nature and that we carry with us our ancient brains and our need to connect with and affiliate with nature, to be happy and healthy (Beatley and Newman 2013). Recent findings even show that there is a strong correlation between the lack of green infrastructures in the urban environment and the increase of allergy-related health problems (Von Hertzen et al. 2011; Hanski et al. 2012). Besides since air pollution and higher concentrations of $\mathrm{CO}_{2}$-induced increases in levels and allergenicity of allergenic pollens may contributing to increasing prevalence of allergic disease and asthma (Haahtela et al. 2013). This means that biomimetic building skins and biophilic cities will be crucial in the near future not only in terms of public health but also in the mitigation of UHI effects.

Since biotechnology is one of the world's fastest growing industries being one of the six Key Enabling Technologies-KETs that will be funded under the EU Framework Programme Horizon 2020 (Pacheco-Torgal 2014) this can also foster the development of start-ups in the field of bio materials and technologies for the construction industry. This is probably one of the most important advantages of the association between civil engineering and biotech areas just because civil engineering is one of the most notorious cases of a desert-like capacity concerning start-up development. This is a key issue because entrepreneurship is a key skill to the development of "start-up businesses, the motor propelling the development of the new economies" (Pacheco-Torgal 2004). Besides as some defend the second half of the twentieth century was the time for the scientific engineer while the twenty-first century will be the time for entrepreneurial engineer (Tryggvason and Apelian 2006; Shi and Vest 2014). This entrepreneurial-based civil engineering is very far from the old and traditional one (Muir-Wood 2012), which has persisted until the twenty-first century and this book intents to start changing. Besides, hot areas usually mean more investigation funds and high capability to attract bright students. The comparison between the impact factor of the journal "Nature nanotechnology" (IF = 31.17) or the journal "Nature biotechnology" $(\mathrm{IF}=32.4)$ with the impact factors of most civil engineering-related journals (usually with an IF below 1.5) gives some insights about this issue. The importance of high impact factor journals in civil engineering can be seen in a recent study (Canas-Guerrero et al. 2013) about the research activity on this field that shows that the "high" impact factor of the Journal of Hazardous Materials (3.93) is one of reasons for its great influence over civil engineering researchers. This hardly constitutes a surprise because due to the existent very high number of journals and papers only the top $10 \%$ will be get read, cited and have an impact (Hamilton 1990, 1991). However, this also shows the absurd of human actions associated to the production of enormous amounts of hazardous materials. The aforementioned study also shows that the average number of citations per paper in the field of civil engineering has been fallen steadily in the last 10 years.

Biotech and biomimetic liaisons can therefore constitute an opportunity to refresh the civil engineering curriculum in order to reverse its low career attractiveness and at the same time contribute to a more sustainable civil engineering industry. This will serve to fulfill ASCE's Vision for Civil Engineering in 2025 
one in which civil engineers are entrusted to create a sustainable world (ASCE 2009).

Many books have been written on the field of biotechnology unfortunately the majority of them have absolutely nothing on civil engineering applications. And even the few that have something only have one or just two chapters on this issue. The literature on biomimetic civil engineering applications is even scarcer. It's easy to understand why that happens. Civil engineering is a very conservative field and its focus has saw little change in the last few decades. For instance, OPC was 50 years ago the most important construction material in this field and it remains still.

This book thus provides essential reading concerning biotechnologies and biomimetics for civil engineering. I hope that all of those involved in this field can benefit from the knowledge contained in the present book, which was kindly assembled by a team of international experts.

\subsection{Book Outline}

Basics of construction microbial biotechnology is the subject of Chap. 2. It includes considerations on the different biotechnological products and biotechnologies for civil engineering. Microorganisms in construction microbial biotechnology are analyzed. The application of microbial biopolymers in the construction industry and in geotechnical engineering is discussed. Biocements and biogrouts are reviewed. This chapter concludes with an analysis on the case of bioremediation of construction sites through biocementation.

Chapter 3 deals with general aspects of biomimetic materials. It includes a brief outline of the discipline and a discussion of general aspects related to the structure and synthesis of natural materials. It reviews the recent progress made in the development of biomimetic materials with improved mechanical resistance, optical, self-cleaning, adhesiveness, and anti-adhesion properties is reviewed with reference made to the most noteworthy examples.

Chapter 4 is concerned with the use of biomimicry as a tool for design for climate change adaptation and mitigation. Different biomimetic approaches to design are discussed and categorized, and a series of case study examples illustrate the benefits and drawbacks of each approach.

Chapter 5 reviews state-of-the-art examples of research concepts and design applications with bio-inspired adaptable solutions for the building envelope. The chapter concludes with an outlook of design support methodologies that can potentially incite the practical uptake of bio-inspired adaptive building skins in the future.

The importance of green building envelopes in promoting biophilic cities is the subject of Chap. 6. A discussion on the green building envelope strategy is included. Its contribution for air quality improvement, temperature regulation and 
insulating properties are reviewed. The chapter also includes an overview on green building details including its costs.

Chapter 7 concerns the use of microalgae photobioreactors (PhBR) as innovative construction systems for the production of bio-energy. An overview on photobioreactors is given. The concept of architectural photobioreactors (A-PhBR) is presented and discussed. Examples of PhBR in facades formed from blocks of translucent glass and of horizontal PhBR for roof and urban fountains are presented. Extensive graphical details are also presented.

The reduction of indoor air pollutants through biotechnology constitutes the subject of Chap. 8. The chapter starts with an analysis on the importance of indoor air pollution and its impact on health costs and human dead's followed by a review on current practices and the history of bioremediation on indoor air. The different air pollutants (volatile organic compounds, carbon dioxide, and others) are discussed. A comparison between physiochemical and biological methods are carried out. Hybrid physiochemical-biological systems, active biofiltration of indoor air, and phytoremediation and horticultural biotechnology are discussed. Considerations on the health benefits of indoor plants unrelated to air quality are included. Microbial systems as well as biological indoor air cleaning commercial systems are reviewed.

Chapter 9 deals with the mechanisms underlying bioinspired self-cleaning (hydrophilicity and hydrophobicity) and to the fields of application of these effects.

Common concepts on wettability are reminded. The different mechanisms of self-cleaning are reviewed and detailed. Examples of hydrophilic and superoleophobic plants and animals are given. The chapter concludes with a section on production techniques and applications which presents examples of biomimetic self-cleaning surfaces, and give details on how they were created.

Chapter 10 reviews the development of the bio-inspired concept on bridge design in the past two decades from two major forms: stationary forms and movable forms. The objective is to show how the inspiration from the biological world has influenced recent bridge designs and discusses how the bio-inspired idea could transform into a new language for the future bridge design industry. Four major challenges of the marriage between biology and engineering were discussed and latest endeavor on each aspect was presented.

Bioinspired sensors for structural health monitoring is the subject of Chap. 11.

Topics ranging from bio-inspired algorithms, creature-like robots, and skin-like sensors are presented.

Chapter 12 deals with bioinspired, flexible structures and materials. The potential of biomimetics in form finding and the development of structural systems based on constant or reversible elastic deformation are discussed. Elastic building materials and biomimetic abstraction techniques are introduced and two case studies are provided.

Bioinspired concrete is the subject of Chap. 13. An overview of Earths minerals is presented. Several bioinspired cements are covered. The environmental challenges with cements and concrete are revewed. 
Chapter 14 describes the production of bacteria for structural concrete reviewing the mechanism of microbially induced calcium carbonate precipitation (MICP).

Chapter 15 deals with the use of bacteria for surface treatment reviewing the main mechanisms of the process and literature on biodeposition carbonates as surface treatment agents for the decrease of permeability of concrete materials and structures.

Chapter 16 describes a case study concerning the use of bacterial surface treatment for normal and lightweight concrete.

Chapter 17 identifies remediation techniques for contaminated soils including physical, chemical, biological, thermal, and other treatments.

Chapter 18 deals with the use of microbial fuel cells (MFCs) for wastewater treatment. The concept of MFCs is introduced, and the materials and design of MFCs are summarized. In-depth discussion of the microbiology of MFCs was also included.

\section{References}

Adeli H (2009) Vision for civil and environmental engineering departments in the 21st century. J Prof Issues Eng Educ Pract 135(1):1-3

Allwood J, Ashby M, Gutowski T, Worrell E (2011) Material efficiency: a white paper. Resour Conserv Recycl 55:362-381

Al-Rawahy KH (2013) Engineering education for sustainable development: the missing link. Proc Soc Behav Sci 102:392-401

Amini S, Miserez A (2013) Wear and abrasion resistance selection maps of biological materials. Acta Biomater 9:7895-7907

ASCE (2009) Achieving the vision for Civil Engineering in 2025. A road map for the profession. ASCE, Virginia

Balaras C, Grossman G, Henning H, Infante-Ferreira C, Podesser E, Wang L, Wiemken E (2007) Solar air conditioning in European overview. Renew Sustain Energy Rev 11:299-314

Bar-Cohen Y (2006) Biomimetics-using nature to inspire human innovation Bioinspir Biomim $1: 1-12$

BBSRC (2012) Biologists and physicists collaborate to investigate 'quantum biology'. http://www. bbsrc.ac.uk/news/research-technologies/2012/121203-f-quantum-biology.aspx. Accessed in 20 June 2014

Beatley T Peter, Newman P (2013) Biophilic cities are sustainable, resilient cities. Sustainability 5:3328-3345

Benyus J (1997) Biomimicry: innovation inspired by nature. Willeam Morrow Paperbacks

Boucher O, Forster P, Gruber N, Ha-Duong M, MLawrence M, Lenton T, aas A, Vaughan N (2014) Rethinking climate engineering categorization in the context of climate change mitigation and adaptation. Clim Change 5:23-35

Brown C (2004) BioBricks to help reverse-engineer life. EE Times. http://www.eetimes.com/ document.asp?doc_id=1150423

Byfield MP (2001) Graduate shortage: the key to civil engineering's future? Proc Inst Civil Eng Civil Eng 144(4):161-165

Byfield MP (2003) British civil engineering skills: defusing the time bomb. Proc Inst Civil Eng Civil Eng 156(4):183-186 
Cañas-Guerrero I, Mazarrón FR, Pou-Merina A, Calleja-Perucho C, Suárez-Tejero MF (2013) Analysis of research activity in the field "Engineering, Civil" through bibliometric methods. Eng Struct 56:2273-2286

Chakraborty S, Iyer N, Krishna P, Thakkar S (2011) Assessment of civil engineering inputs for infrastructure development. Indian Natl Acad Eng

Chen P-Y, McKittrick J, Meyers M (2012) Biological materials: functional adaptations and bioinspired designs. Prog Mater Sci 57:1492-1704

Clayton R (2001) Editorial: Is sustainable development an oxymoron? Trans I Chem E 79(Part B): $327-328$

COM (2011) 571 final. Roadmap to a resource efficient Europe

Crawley DB (2008) Estimating the impacts of climate change and urbanization on building performance. J Build Perform Simul 1:91-115

Dator J (2005) Universities without quality and quality without universities. On Horiz 13(4):199-215. Q Emerald Group Publishing Limited, ISSN 1074-8121

Denghai X, Wuyi C (2011) Systematic method of applying structural characteristics of natural organisms to mechanical structures. Trans Tianjin Univ 17:293-297

De Vere I, Bissett Johnson K, Thong C (2009) Educating the responsible engineer: socially responsible design and sustainability in the curriculum. In: EPDE09/134, International conference on engineering and product design education, 10-11 September 2009. University of Brighton, UK

Edwards DJ, Dainty ARJ, Love PED (2004) A sustainable cohort of professional civil engineering graduates? Uncovering the United Kingdom graduate crisis. Int Educ J 5(3):374-384

Engel GS, Calhoun TR, Read EL et al (2007) Evidence for wavelike energy transfer through quantum coherence in photosynthetic systems. Nature 446:782-786

Friedman N, Ibrahimbegovic A (2013) Overview of higly flexible, deployable lattice structures used in architecture and civil engineering undergoing large displacements. J Built Environ $1: 85-103$

Fuller RB (1962) Tensile-integrity structures. US Pat 3063521

Garcia R, Cabeza M, Rahbek C, Araujo M (2014) Multiple dimensions of climate change and their implications on biodiversity. Science 2(3844):6183

Gebeshuber IC, Majlis BY (2010) New ways of scientific publishing and accessing human knowledge inspired by transdisciplinarity. Tribology 4:144-151

Gebeshuber IC, Gruber P, Drack M (2009) A gaze into the crystal ball: biomimetics in the year 2059. Proc IMechE Part C: J Mech Eng Sci 223:2899-2918

Georgescu M, Morefield P, Bierwagen B, Weaver C (2014) Urban adaptation can roll back warming of emerging megapolitan regions. Proc Natl Acad Sci USA PNAS 111:2909-2914

Girst MD, Raskin PD, Rockstrom J (2014) Contours of a resilient global future. Sustainability 6:123-125

Glass J, Dyer T, Georgopoulos C, Goodier C, Paine K, Parry T, Baumann H, Gluch P (2013) Future use of life-cycle assessment in civil engineering. Proc ICE Constr Mater 166:204-212

Grasso D, Burkins M, Helble J, Martinelli D (2010) Dispelling the myths of holistic engineering. In holistic engineering education: beyond technology. Springer, New York, pp 159-166

Griggs D, Stafford-Smith M, Gaffney O, Rockström J, Öhman MC, Shyamsundar P, Steffen W, Glaser G, Kanie N, Noble I et al (2013) Policy: sustainable development goals for people and planet. Nature 495:305-307

Haahtela T, Holgate S, Pawankar R, Akdis C, Benjaponpitak S, Caraballo L, Demain J, Portnoy J, Von Hertzen L, WAO Special Committee on Climate Change and Biodiversity (2013) The biodiversity hypothesis and allergic disease: world allergy organization position statement. World Allergy Organ J 6:3

Hamill L, Hodgkinson L (2003) Civil engineering's image in schools-and how to change it. Proc ICE Civil Eng 156(2):78-85

Hamilton DP (1991) Research papers: Who's uncited now? Science 251:25

Hamilton DP (1990) Publishing by and for the numbers? Science 250:1331-1332 
Hansen J et al (2013) Assessing "Dangerous Climate Change": required reduction of carbon emissions to protect young people. Future generations and nature. PLOS One. doi:10.1371/ journal.pone. 0081648

Hanski I, Von Hertzen L, Fyhrquist N, Koskinen K, Torppa K, Laatikainen T, Karisola P, Auvinen P, Paulin L, Mäkelä M, Vartiainen E, Kosunen T, Alenius H, Haahtela T (2012) Environmental biodiversity, human microbiota, and allergy are interrelated. Proc Natl Acad Sci USA. http://www.pnas.org/content/early/2012/05/01/1205624109.full.pdf

Helms M, Vattam S, Goel A ( 2009) Biologically inspired design: process and products. Des Stud 30:606-622

Hofstra N, Huisingh D (2014) Eco-innovation characterizaed: a taxonomic classification of relationships between humana and nature. J Clean Prod 66:459-468

Holmberg J, Svanström M, Peet DJ, Mulder K, Ferrer-Balas D, Segalàs J (2008) Embedding sustainability in higher education through interaction with lecturers: case studies from three European technical universities. Eur J Eng Educ 33(3):271-282

IEA (2012) World Energy Outlook 2012. OECD/IEA, Paris

Ingber DE (1998) The architecture of life. Sci Am Mag 278:48-57. http://pt.scribd.com/doc/ 35190367/Architecture-of-Life-Scientific-American-by-Ingber

Kaklauskas A, Pacheco-Torgal F, Grafakos S, Lapinskiene V (2013) Built environment life cycle process and climate change. In: Pacheco-Torgal F, Mistretta M, Cabeza L, Kalauskas A, Granqvist CG (eds) Nearly zero energy building refurbishment. A multidisciplinary approach. Springer, London, UK, pp 61-97

Kaku M (2010) The Bizarre and wonderful world of quantum theory-and how understanding it has ultimately changed our lives. http://bigthink.com/dr-kakus-universe/the-bizarre-andwonderful-world-of-quantum-theory-and-how-understanding-it-has-ultimately-changed-ourlives. Accessed on 20 June 2014

Kawaguchi M (2002) Preface. In: Motro R (ed) Tensegrity: structural systems for the future. Butterworth-Heinemann, Oxford (2006)

Krausmann F, Gingrich S, Eisenmenger N, Erb K-H, Haberl H, Fischer-Kowalski M (2009) Growth in global materials use, GDP and population during the 20th century. Ecol Econ 68:2696-2705

Kwok A, Rajkovich N (2010) Addressing climate change in comfort standards. Build Environ 45:18-22

Lawless A (2005) A wake up call to address the capacity crisis in SA civil engineering. Civil Eng/ Siviele Ingenieurswese 13(10):40-43

Lepora N, Verschure P, Prescott T (2013) The state of the art in biomimetics. Bioinspir Biomim 8:013001

Li Y, Yang 1, He B, Zhao D (2014a) Green building in China: Needs great promotion. Suatain Cities Soc 11:1-6

Li Y, Wang X, Zhu Q, Zhao H (2014b) Assessing the spatial and temporal differences in the impacts of factor allocation and urbanization on urban-rural income disparity in China, 2004-2010. Hatitat Int 42:76-82

Li D, Yang L, Lam J (2013) Zero energy buildings and sustainable development implications-a review. Energy 54:1-10

Loonen RCGM (2014) Climate adaptive building shells. http://www.pinterest.com/ CABSoverview/

Lowdin P-O (1963) Proton tunneling in DNA and its biological implications. Rev Mod Phys 35(3):724-732

Lozano R (2010) Diffusion of sustainable development in universities' curricula: an empirical example from Cardiff University. J Clean Prod 18(7):637-644

Lozano R (2006) Incorporation and institutionalization of SD into universities: breaking through barriers to change. J Clean Prod 14(9-11):787-796

Martin J, Roy E, Diemont S, Fergunson B (2010) Traditional ecological knowledge (TEK): ideas, inspiration, and designs for ecological engineering. Ecol Eng 36:839-849 
McMillan Malcolm, Shepherd Andrew et al (2014) Increased ice losses from Antarctica detected by CryoSat-2'. Geophys Res Lett. doi:10.1002/2014GL060111

Meadows DL, Meadows DH, Behrene JRW (1972) The limits to growth. MIT Press, Boston

Meadows DL, Meadows DH, Randers J (1992) Beyond the limits: global collapse or a sustainable future. Earthscan, London

Muir-Wood D (2012) Civil engineering: a very short introduction. Oxford University Press, Oxford, UK

Myers N, Mittermeier RA, Mittermeier CG, da Fonseca GAB, Kent J (2000) Biodiversity hotspots for conservation priorities. Nature 403:853-858

Nehdi M (2002) Crisis of civil engineering education in information technology age: analysis and prospects. J Prof Issues Eng Educ Pract 128(3):131-137

Nicolaou I, Conlon E (2012) What do final year engineering students know about sustainable development? Eur J Eng Educ 37(3):267-277

IPCC (Intergovernmental Panel on Climate Change) (2007) Climate Change 2007: synthesis report. IPCC, Geneva

Pacheco-Torgal $\mathrm{F}$ (2015) Introduction to eco-efficient materials for mitigating building cooling needs. In: Pacheco-Torgal F, Labrincha JA, Cabeza 1, Granqvist CG (eds) Eco-efficient materials for mitigating building cooling needs Woodhead Publishing Limited Abington Hall, Cambridge, UK (in press)

Pacheco-Torgal F (2014) Eco-efficient construction and building materials research under the EU framework programme Horizon 2020. Constr Build Mater 51:151-162

Pacheco-Torgal F, Cabeza L, Mistretta M, Kaklauskas A, Granqvist CG (2013a) Nearly zero energy building refurbishment. A multidisciplinary approach. Springer, London, UK

Pacheco-Torgal F, Labrincha JA, Jalali S, John VM (2013b) Eco-efficient concrete. Woodhead Publishing Limited Abington Hall, Cambridge, UK $592 \mathrm{p}$

Pacheco-Torgal F, Jalali S (2011) Eco-efficient construction and building materials. Springer, London, UK

Pacheco-Torgal F, Jalali S (2007) Does engineering students need sustainable development courses? In: ICEE 2007 international conference on engineering education-The moving frontiers of engineering, Coimbra

Pacheco-Torgal F (2004) EST-IPCB civil engineering curricula design. A proposal. Itinerary Mag (Institute of Educational Sciences) 157-180 (only in Portuguese)

Planck J (2005) Applications of biopolymers in construction engineering. Biopolymers Online 29-39. http://www.wiley-vch.de/books/biopoly/pdf_v10/vol10_17.pdf

Pimm SL, Raven P (2000) Biodiversity. Extinction by numbers. Nature 403:843-845

Plank J (2004) Application of biopolymers and other biotechnological products in building material. Appl Microbiol Biotechnol 66:1-9

Rai A (2010) Unstandard standardization: the case of biology. Commun ACM 53:37-39

Reckien D, Flacke J, Dawson R, Heidrich O, Olazabal M, Foley A, Hamann J-P, Orru H, Salvia M, De Gregorio Hurtado S, Geneletti D, Pietrapertosa F (2014) Climate change response in Europe: what's the reality ? Analysis of adaptation and mitigation plans from 200 urban areas in 11 countries. Clim Change 122:331-340

Reichert S, Menges A, Correa D (2014) Meteorosensitive architecture: biomimetic building skins based on materially embedded and hygroscopically enabled responsiveness. Comput Aided Des (in press)

Rhode-Barbarigos LGA, Bel Hadj ALI N, Motro R, Smith IFC (2012) Design aspects of a deployable tensegrity-hollow-rope footbridge. Int J Space Struct 27:81-96

Rizwan A, Dennis L, Liu C (2008) A review on the generation, determination and mitigation Urban Heat Island. J Environ Sci 20:120-128

Roetzel A, Tsangrassoulis A (2012) Impact of climate change on comfort and energy performance in offices. Build Environ 57:349-361

Rockström J, Steffen W, Noone K, Persson Å, Chapin FS, III, Lambin E, Lenton TM, Scheffer M, Folke C, Schellnhuber H, Nykvist B, De Wit CA, Hughes T, van der Leeuw S, Rodhe H, Sörlin S, Snyder PK, Costanza R, Svedin U, Falkenmark M, Karlberg L, Corell RW, Fabry 
VJ, Hansen J, Walker B, Liverman D, Richardson K, Crutzen P, Foley J (2009) Planetary boundaries: exploring the safe operating space for humanity. Ecol Soc 14(2):32. http://www. ecologyandsociety.org/vol14/iss2/art32/

Salcedo-Rahola B, Mulder K (2009) European sustainable development master report. What has Europe got to offer? TU Delft

Sanchez C, Arribart H, Guille MMG (2005) Biomimetism and bioinspiration as tools for the design of innovative materials and systems. Nat Mater 4:277

Sarikaya M, Tamerler C, Jen AK-Y, Schulten K, Baneyx F (2003) Molecular biomimetics: nanotechnology through biology. Nat Mater 2(9):577-585

Sarovar M, Ishizaki A, Fleming G, Whaley B (2010) Quantum entanglement in photosynthetic light harvesting complexes. Nat Phys 6:462-467

Schellnhuber H (2008) Global warming. Stop worrying, start panicking? Proc Natl Acad Sci USA 105:14239-14240

Schleicher S, Lienhard J, Poppinga S, Speck T, Knippers J (2014) A methodology for transferring principles of plant movements to elastic systems in architecture. Comput Aided Des (in press)

Seto KC, Buneralp B, Hutyra LR (2012) Global forecasts of urban expansion to 2030 and impacts on biodiversity and carbon pools. PNAS 109(40):16083-16088

Shi H, Vest C (2014) Higher engineering education for the 21st century: American perspective and its implications for China. In: International conference on education reform and modern management. Atlantis Press, pp 139-143

Shimomura M (2010) The new trends in next generation biomimetics material technology: learning from biodiversity. Sci Technol Trends Q Rev 3(7):53-75

Singh A (2007) Civil engineering: anachronism and black sheep. J Prof Issues Eng Educ Pract 133(1):18-30

Snelson K (1965) Continuous tension, discontinuous compression structures. US Pat 3(169):611

Spence M, Annez PC, Buckley RM (2009) Urbanization and growth (Commission on growth and development). The International Bank for Reconstruction and Development, The World Bank

Tryggvason G, Apelian D (2006) Re-engineering engineering education for the challenges of the 21st Century. JOM 58(10):14-17

Valero A, Agudelo A, Valero A (2011) The crepuscular planet. A model for the exhausted atmosphere and hydrosphere. Energy 36:3745-3753

Varadan V, Pillai A, Mukherji D, Dwivedi M, Chen L (2010) Nanoscience and nanotechnology in engineering. World Scientific Publishing Company, Singapore

Varias N (2013) Brainstorming for a beautiful planet. ISBN 1484851331

Vedral V (2014) Quantum entanglement. Nat Phys 10:256-258

Vijayavenkataraman S, Iniyan S, Goic R (2012) A review of climate change, mitigation and adaptation. Renew Sustain Energy Rev 16(1):878-897

Vincent JFV (2006) Applications-influence of biology on engineering. J Bionic Eng 3(3):161-177

Vincent JFV, Bogatyreva O, Bogatyrev N, Bowyer A, Pahl A-K (2006) Biomimetics: its practice and theory. J R Soc Interface 22:9471-9482

Vincent JFV, Mann DL (2002) Systematic technology transfer from biology to engineering. Philos Trans R Soc Lon A 360:159-173

Vincent JFV (2001) Stealing ideas from nature. In: Pellegrino S (ed) Deployable structures. Springer, Vienna

Vincent J (2007) Re: Designing around existing patents through TRIZ, personal email communication, 5 May

Von Hertzen L, Hanski I, Haahtela T (2011) Natural immunity. Eur Mol Biol Organ EMBO Rep 12:1089-1093

Waheed B, Khan F, Veitch B, Hawboldt K (2011) An integrated decision-making framework for sustainability assessment: a case study of memorial University. High Educ Policy 24(4):481-498 
Watson MK, Lozano R, Noyes C, Rodgers M (2013) Assessing curricula contribution to sustainability more holistically: experiences from the integration of curricula assessment and students' perceptions at the Georgia Institute of Technology. J Clean Prod 61(2013):106-116

Whitmore A (2006) The emperor's new clothes: sustainable mining. J Clean Prod 14:309-314

WHO (2014) Urban population growth. Global health observatory. http://www.who.int/gho/ urban_health/situation_trends/urban_population_growth_text/en/

Willis A (2012) Constructing a story to live by: ethics, emotions and academic practice in the context of climate change. Emot Space Soc 5:52-59

Yang W, Chao C, McKittrick J (2013) Axial compression of a hollow cylinder filled with foam: a study. Acta Biomater 9:5297-5304

Yurtseven $\mathrm{H}$ (2002) How does the image of engineering affect student recruitment and retention? A perspective from the USA. Glob J Eng Educ 6(1):17-23

Zielinski W (2003) Vision of an engineer in the 21st century. In: Juan S (ed) 9th International conference on engineering education

Zuo J, Zhao Z-Y (2014) Green building research-current status and future agenda: a review. Renew Sustain Energy Rev 30:271-281 